\title{
Recycling of the Powder-pack Boriding Mixture: Microstructural Characterization of Fe2B Layers on ASTM A36 Steel
}

Martín Ortiz-Domínguez ${ }^{1}$, Ángel Morales-Robles ${ }^{2}$, Oscar Gómez-Vargas ${ }^{3}$ and Jose Solis-Romero ${ }^{3}$

${ }^{1}$ Universidad Autónoma del Estado de Hidalgo, Ciudad Sahagún, Hidalgo, Mexico, ${ }^{2}$ Universidad Autónoma del Estado de Hidalgo, Mineral de la Reforma, Hidalgo, Mexico, ${ }^{3}$ Instituto Tecnológico de Tlalnepantla, Estado de México, México, Distrito Federal, Mexico

The development of materials has been parallel to the evolution of civilizations, and human beings have used them to manufacture various types of elements (instruments, equipment, and machines) that have allowed them to improve their standard of living and facilitate tasks that would not have been possible without them. Today, they are a fundamental part of the economy and both scientists and engineers carry out research aimed either at producing new materials or modifying existing ones to improve their properties. This search is since, in general, the elements constituent parts of machines, equipment or instruments are subjected to different types of physical and/or chemical phenomena which may lead to a gradual loss of functional integrity and performance of the engineering system to which belong as a result of degradation processes such as corrosion, wear, fatigue, etc. In this regard, hard layers are particularly useful in abrasive environments. The low coefficient of friction can be achieved if microfilm with low shear strength is present on the upper surface of the hard layer. Then shearing takes place in the microfilm, and the load is transmitted well through the hard shell. A thick hard layer can help a soft substrate in carrying the loads and thus reduce the contact area and friction. Thin hard coatings on soft surfaces are susceptible to cracking due to stress-induced by deformations of the substrate. A hard protective layer should be as smooth as possible. Although the rough surface reduces the effective contact area, the asperities may be exposed to abrasive wear or fatigue, generating wear particles. The most common treatments in the industry are carburization, nitriding, carbonitriding and boriding. Boriding is a thermochemical treatment controlled by the diffusion of boron atoms, which modifies the properties of the material generating hard surfaces. Likewise, the boriding process has a positive effect on the tribological applications abrasive, adhesive, fatigue and corrosion wear in acid and alkaline media. The process involves heating a ferrous or non-ferrous alloy for a temperature range of 700 to $1000^{\circ} \mathrm{C}$ with a treatment time of 1 to 12 hours for powder-pack methods. When boron diffuses in a substrate, a monolayer $\left(\mathrm{Fe}_{2} \mathrm{~B}\right)$ or a double layer $\left(\mathrm{FeB}-\mathrm{Fe}_{2} \mathrm{~B}\right)$ can be formed, depending on the chemical composition of the substrate and the chemical potential of boron. These phases consist of orthorhombic and tetragonal lattices (body-centered) respectively. One basic advantage of boride layers is that they can reach high hardness values (between 1800-2000 HV), kept at high temperatures [1-8]. In the present study, the microstructure of the single phase layer $\left(\mathrm{Fe}_{2} \mathrm{~B}\right)$ and the recycling of the powder-pack boriding mixture until it is no longer possible to form any layers on the surface of the ASTM A36 borided steel have been investigated at 1173 $\mathrm{K}$ with exposure time of $2 \mathrm{~h}$ by dehydrated paste-pack method. The thermochemical treatment was conducted on cubic commercial samples of ASTM A36 with a thickness of $5 \mathrm{~mm}$. Boriding heat treatment was carried out by using dehydrated paste-pack boriding method that is similar to pack carburizing process. Boriding mixture contains of $\mathrm{B}_{4} \mathrm{C}$ (active source of boron), $\mathrm{Na}_{3} \mathrm{AlF}_{6}$ (activator), $\mathrm{SiC}$ (inert filler), and $\mathrm{SiC}_{8} \mathrm{H}_{20} \mathrm{O}_{4}$ which is used to protect surfaces. The samples were embedded in a closed, cylindrical case at $1173 \mathrm{~K}$ for time up to $2 \mathrm{~h}$ using the same $\mathrm{B} 4 \mathrm{C}$-base powder (see Figure 1). The powder-pack boriding process was carried out in a conventional furnace under a pure argon atmosphere. One the boriding treatment was finished each container was removed from the furnace and slowly cooled to room 
temperature. The hard samples were cross-sectioned and resin-embedded for traditional metallographic preparation; were grinded with $\mathrm{SiC}$ abrasive paper up to grit 2500. Afterwards, the samples were polished using a diamond suspension with particle size of $6 \mu \mathrm{m}$, finishing with particle size of $3 \mu \mathrm{m}$, then the polished samples were etched in a $2 \%$ nital solution to observe the boride layer depths formed on the surface of ASTM A36. The boride layer depths and morphology were analysed by Scanning Electron Microscopy (SEM) and Energy Dispersive Spectroscopy (EDS) on the surface of the borided ASTM A36. Figures 2 and 3a-g shows the cross-sections of boride layers formed on the surface of ASTM A36 at 1173 $\mathrm{K}$ for $2 \mathrm{~h}$. The formation of the single-pahse boride layer $\left(\mathrm{Fe}_{2} \mathrm{~B}\right)$ was revealed with a sawtooth structure as indicated in Figures 2 and $3 \mathrm{a}-\mathrm{g}$. This structure helps to improve the mechanical adherence at the $\mathrm{Fe}_{2} \mathrm{~B} /$ substrate interfaces. In Figure $3 \mathrm{~h}$, the $\mathrm{Fe}_{2} \mathrm{~B}$ layer disappears due to the chemical composition of the boriding mixture. It confirms that the iron diboride $\left(\mathrm{Fe}_{2} \mathrm{~B}\right)$ is easily identified on the surface of borided ASTM A36. The EDS analysis obtained by SEM at the $\mathrm{Fe}_{2} \mathrm{~B}$ layer is shown in Fig. 4a and the Fe-substrate (ASTM A36 steel) is shown in Fig. 4b. Finally, as can be seen in Figures 2 and 3, the formation of the $\mathrm{Fe}_{2} \mathrm{~B}$ phase on the surface of the ASTM A36 steel could be achieved up to seven times with the same powder-pack boriding mixture (see Figures 2 and 3a-g), the thicknesses of borided layers also logically decreased as expected. The intention of carrying out these treatments is to quantify the extent to which it is possible to reuse the powder-pack boriding mixture, since in all the treatments carried out the chemical is used only once and then discarded (Waste minimization is the process and policy of reducing the amount of waste produced by a person or a society. Waste minimization involves efforts to minimize resources and energy use during manufacturing. With the same volume of commercial production, generally less material used leads to less waste produced).

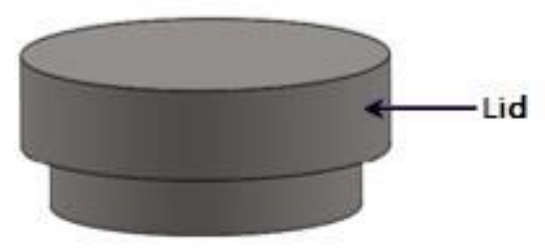

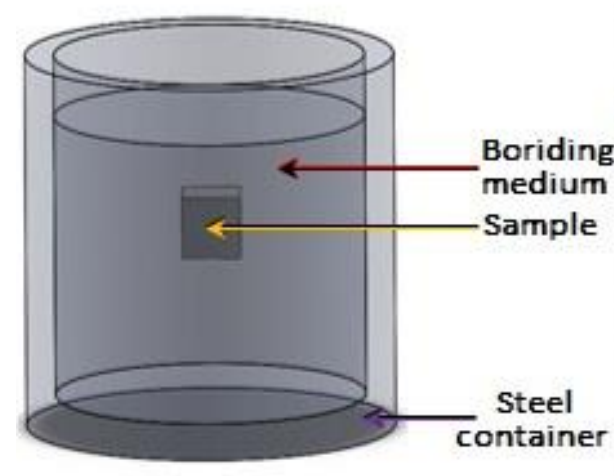

Fig. 1
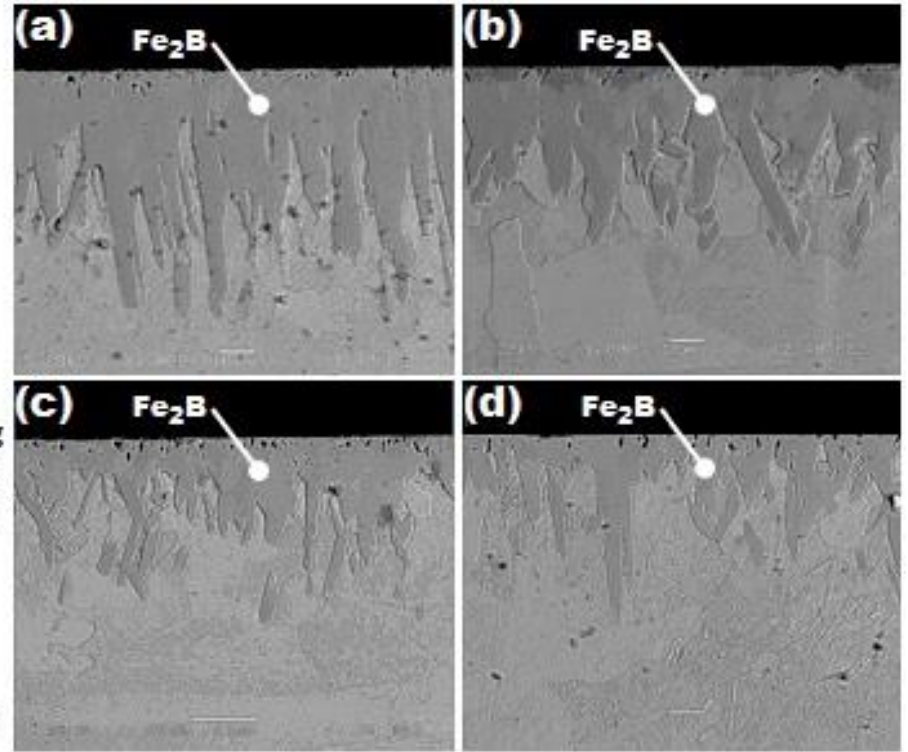

Fig. 2

Figure 1. (Figure 1) Schematic view of the stainless steel AISI 316L container for the powder-pack boriding treatment and images (SEM) cross-sectional of borided ASTM A36 showing the produced layers (Figure 2). 


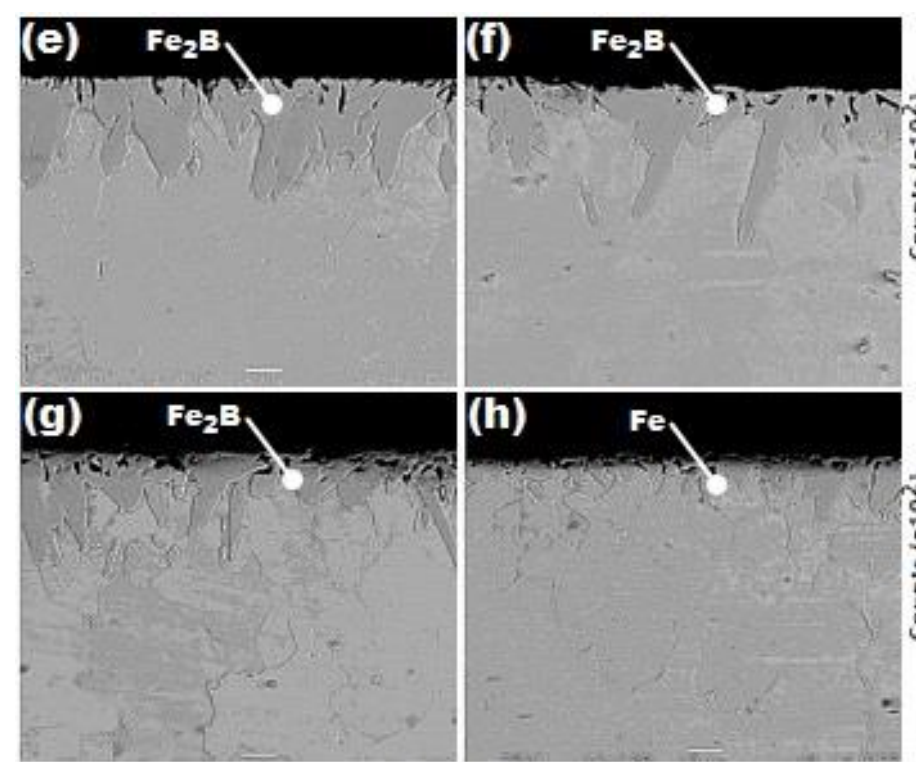

Fig. 3
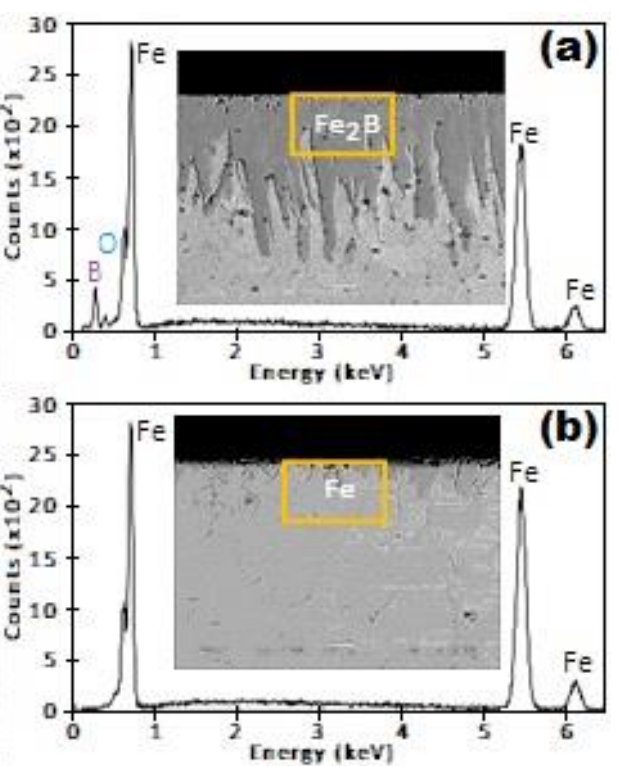

Fig. 4

Figure 2. (Figure 3) Images (SEM) cross-sectional of borided ASTM A36 showing the produced layers and EDS (Figure 4) spectrum of borided sample at Fe2B layer (a) at $1173 \mathrm{~K}$ for 2 hours of treatment (the first stage of the thermochemical treatment) and (b) Fe substrate (ASTM A36 steel).

\section{References}

[1] J. R. Davis. "Surface Hardening of Steels: Understanding the Basics", 1st ed. ASM, Ohio, p. 213.

[2] M. Ortiz-Domínguez, I. Morgado-González, A. Cruz-Avilés, A. Soto-García, R. Trujillo-Sánchez, M. L. Moreno-González, G. Moreno-González, O. A. Gómez-Vagas, J. Zuno-Silva, Microsc.Microanal. 25 (Suppl 2) 2019, p. 2400.

[3] M. Ortiz-Domínguez, O. A. Gómez-Vargas, I. Simón-Marmolejo, M. A. Flores-Rentería, L. E. Martínez-Martínez, A. Cruz-Avilés, M. A. Paredes-Rueda, Microsc. Microanal. 24 (Suppl 1) 2018, p. 1076.]

[4] O. A. Gómez-Vagas, M. Ortiz-Domínguez, A. Cruz-Avilés, I. Morgado-González, J. Solis-Romero, V. A. Castellanos-Escamilla, E. Coronel-Guerra, E. Cardoso-Legorreta, Microsc. Microanal. 25 (Suppl 2) 2019, p. 770.

[5] O. A. Gómez-Vargas, M. Ortiz-Domínguez, J. Solís-Romero, A. Arenas-Flores, I. Morgado González, J. Zuno-Silva, F. R. Barrientos-Hernández and J. Medina-Marín, Microsc. Microanal. 25 (Suppl 2) 2019, p. 796.

[6] M. Ortiz-Domínguez, O. A. Gómez-Vargas, G. Ares de Parga, G. Torres-Santiago, R. VelázquezMancilla, V. A. Castellanos-Escamilla, J. Mendoza-Camargo, and R. Trujillo-Sánchez, Advances in Materials Science and Engineering. 2019 (2019), p. 1.

[7] Graf von Matuschka A. "Boronizing", 1 st ed. Carl Hanser Verlag, Munich, p. 12.

[8] K. H. Habig. Wear protection of steels by boriding, vanadizing, nitriding, carburizing, and hardening. Mater. Eng. 2 (1980) p. 83. 